\title{
Modern Law Aspect on Procedural Decision of Sultan Adam Law
}

\author{
Ahmadi Hasan, ${ }^{1}$ Anwar Hafidzi, ${ }^{2}$ Yusna Zaidah ${ }^{3}$ \\ ${ }^{1}$ Sekolah Pascasarjana UIN Antasari, Banjarmasin, ${ }^{2,3}$ Fakultas Syariah UIN Antasari \\ Banjarmasin \\ 1ahmadihasan58@yahoo.com, ${ }^{2}$ anwar.hafidzi@uin-antasari.ac.id, ${ }^{3}$ yusnazaidah@uin- \\ antasari.ac.id
}

\begin{abstract}
The main focus of this research was analyzing the normative procedural decision of Sultan Adam Law which was applied by Sultan Adam during 1835 AD. Its emergence was for strengthening Islam Aqeedah for its believers and clinging on to Syafii Madhhab. Sultan Adam Law was remarkable to scrutinize, especially when associated with the modern law aspect. By employing the law history approach, this research attempted to respond to Sultan Adam Law procedural decision document issues which were associated with the modern law aspect. It could be seen through several sides such as political law, law substance, arrangement system as well as procedural aspect. The research also responded on how several factors explained Sultan Adam Law included in modern law. Based on the analysis result, it could be concluded that Sultan Adam Law was a written law decision which its existencein Banjarese people contained principles and legal norms as well as several procedural law decisions in a modern way. Although it was simple systematics which did not classify based on article and section, it contained several decision or principles and legal norms.
\end{abstract}

Keywords: law history; Sultan Adam Law (SAL); modern law; procedural decision

[]

Fokus kajian ini adalah menelaah secara normative ketentuan prosedural UndangUndang Sultan Adam yang diterapkan oleh Sultan Adam pada sekitar tahun 1835. Tujuan diundangkannya adalah dalam rangka meneguhkan aqidah Islam yang diyakini oleh rakyat dan agar seluruh rakyat berpegang teguh kepada mazhab syafii. Sebagai dokumen hukum UUSA menarik untuk dikaji terutama jika dikaitkan dengan aspek hukum modern. Dengan menggunakan pendekatan sejarah hukum penelitian ini berupaya menjawab persoalan ketentuan procedural dokumen UUSA dikaitkan aspek hukum modern. Hal tersebut dapat dilihat baik dari sisi politik hukum, substansi hukum, sistematika susunan maupun dari aspek proseduralnya. Bagaimana factorfaktor yang dapat menjelaskan bahwa UUSA termasuk bagian Dari hukum modern. Dari telaah yang dilakukan mendapatkan fakta UUSA merupakan ketentuan hukum tertulis yang hidup pada masyarakat Banjar yang memuatasas dan norma hukum yang memuat beberapa ketentuan procedural hukum secara modern, meskipun sistematikanya masih sederhana tidak terurai berdasarkan pasal dan ayat, namun mencakup beberapa ketentuan atau norma dan asas hukum.

Kata kunci: sejarah hukum; Undang-Undang Sultan Adam; hukum modern; ketentuan prosedural 


\section{Introduction}

In Banjar Kingdom history, it officially conducted law codification and stated Islam Sharia as official law which ruled Islam people in Banjar during the reign of Sultan Adam al Watsiq Billah bin Sultan Sulaiman al-Mu'tamidillah. ${ }^{1}$ It was indicated by issuing Sultan Adam Law. Sultan Adam Law (SAL) 1835 was issued by Sultan Adam Al Wastiq Billah, The King of Banjar on 1825-1857 A.D.2 It was 10 years after his coronation. As a historical document, it contained a living law of Banjarese which was maintained by the Banjar Kingdom. ${ }^{3}$

During SAL establishment, Sultan Adam planned to issue and complete the rule made based on Islamic law. ${ }^{4} \mathrm{He}$ intended to keep law clarity, which was applied, and government system was ruled well based on Islamic guideline. 5 Then, based on Syekh Arsyad Al Banjari (royal advisor of Banjar Kingdom) recommendation, Islamic institution was established in the government, named Sharia Court. ${ }^{6}$ Sharia court was led by a mufti who managed law issues and resolved any legal disputes such as family law, mu'ämmalah, and many more. In performing their duty, judges were assisted by qāḍ̂̄ ${ }^{7}$ This $Q \bar{a} d \underline{i} \bar{i}$ institution was

1Nisa Ushulha, 'Kerajaan Banjar Dan Perang Banjar(1859-1905 M)' (UIN Sunan Ampel Malang, 2016), 15-23; Muhammad Siddiq Armia, 'Sumbangsih Kerajaan Muslim Indonesia Dalam Pengembangan Peradilan Islam: Analisis Historical Legal Approach', Jurnal Justicia: Jurnal Ilmu Hukum, Perundang-undangan dan Pranata Sosial 2, no. 2 (2017): 180183.

${ }^{2}$ Hendra Gunawan, 'Potret Perjalanan Hukum Islam Di Indonesia', Jurnal AL-MAQASID: Jurnal Ilmu Kesyariahan dan Keperdataan 4, no. 1 (2018): 45; M. Faqih Ridha, 'Potret Lain Perjalanan Hukum Di Kerajaan Banjar', Al-Banjari : Jurnal Ilmiah Ilmu-Ilmu Keislaman 12, no. 1 (August 14, 2015), 2-3.

${ }^{3}$ W. Ph Coolhaas, A Critical Survey of Studies on Dutch Colonial History (Springer Science \& Business Media, 2013), 52; Ahmad Satori, Sketsa Pemikiran Politik Islam, ed. Akhmad Satori dan Sulaiman Kurdi, 1st ed. (Yogyakarta: Deepublish, 2016), 257-259.

${ }^{4}$ Herlambang Perdana Wiratraman, 'Perkembangan Politik Hukum Peradilan Adat', Jurnal Mimbar Hukum 30, no. 3 (2018): 488-503.

${ }^{5}$ Muhammad Siddiq Armia, 'Sumbangsih Kerajaan Muslim Indonesia Dalam Pengembangan Peradilan Islam: Analisis Historical Legal Approach', 184.

${ }^{6}$ Ahmad Suriadi, Syekh Muhammad Arsyad Al-Banjari Dalam Dinamika Politik Kerajaan Banjar Abad XIX (Pusat Penelitian dan penerbitan LP2M IAIN Antasari, 2014), 20-21.

${ }^{7}$ Mufti represented as a supreme court judge. Mufti leads Sharia court to supervise district court. A mufti should be devout men and master Islamic law comprehensively. Institutionally, mufti gave advice and suggestion the sultan while the qadli position was being under mufti whose duty was law upholders and organized court process carefully. Qadli also organized and resolve Islamic law cases such as civil law, marriage, and inheritance. 
the forerunner of Kerapatan Qadli (Religious Court) and Kerapatan Qadli Besar (Religious High Court) in South Kalimantan.

As a strict Islamic observance sultan, Sultan Adam had succeeded in applying the Islamic law in the Banjar Kingdom and Banua Lima which he manifested in one single law. Therefore, his people performed ahl al-sunnah wa al-jamä'ah guidance and Islamic institution was incorporated in the government system.

The history showed SAL script was the only one historical document which was the heritage of Banjar Kingdom (1526-1860). As the constitution made by the authority at that time, SAL contained the order of national, religious, and social life. Sultan Adam had established the law for the royal government and his people in the form of codification rule which was emphasized on Islamic law. ${ }^{8}$ SAL described that Sultan in the Banjar Kingdom not only as a power holder but also Ulil Amri of Muslim people in his area. ${ }^{9}$ Therefore, SAL existence was noteworthy research to respond to how normative procedural decision of Sultan Adam Law related to the existence of court at that time as part of modern law embodiment.

This research is a normative legal research using library data. The main source used is SAL 1835 A.D, while the secondary source is all the literature relating to the study theme in this paper. In this study, an approach referred to effort in research activities to build a relationship between men or methods in pursuance of the research problem description.10 This research employed a historical approach to explore the appearance and development of Sultan Adam Law at that time. Furthermore, the researcher utilized the conceptual approach to obtain scientific explanation and truth of normative research on the procedural decision of SAL.

\section{Modern Law and Dispute Resolution}

Modern law theory states that law is norm made by men and born based on agreements among them through negotiation for consensus and autonomy process. It is processed logically, mechanically and regularly way. Modern law theory is part of law theory that the study of the rule of law theory or law

8Ridha, 'Potret Lain Perjalanan Hukum Di Kerajaan Banjar', 4. 72.

9Suparman Jassin, Sejarah Peradilan Islam (Bandung: Pustaka Setia, 2015), 66-80, 70 -

10Martin Bulmer, Sociological Research Methods (Routledge, 2017), 4-5. 
doctrine is stated as positive or codified through logically and mechanically legislative agreement. As a result, a positive law system is established based on applicable rules and neutral as part of ius constitutum. ${ }^{11}$

The concept of science has the main role in modern law. Modern law acts as instrumental which applies a rational way to achieve its aim. Science refers to reason or thought and proven the empirical method to find the truth. Science validates the law and became the foundation of trust. ${ }^{12}$ Modern law takes advantage of experts and conformed them to their intellectual superiority. Here, experts not only make but also apply the law. Another characteristic of modern law culture is it committed to uniformity. The law system should be uniformity, well-organized and systematization.

Furthermore, modern law is a law system that reflects justice for people based on their condition. It should be appropriate with established procedures. "modern law" term first appeared on 18/19 A.D when the life system moved to the modern era ${ }^{13}$. This era is remarked as social change, especially from urban people into an industrial society. ${ }^{14}$ Besides, social change is portrayed as contrasting the relationship between "natural and isolated" family, village and city and "artificial and isolated" urban life and industrial society which realistic and natural human relationship is ruled out and every people compete for their needs. ${ }^{15}$

Here are the following modernity characteristics in the law field:
a. In the form of a written document
b. Law is valid for the whole country

\footnotetext{
${ }^{11}$ Achmad Ali, Menguak Teori Hukum (Legal Theory) Dan Teori Peradilan (Judicial Prudence) Termasuk Interpretasi Undang-Undang (Legis Prudence) (Kencana Prenada Media Group, 2009), 243-245.

${ }^{12}$ Marko Novak and Vojko Strahovnik, Modern Legal Interpretation: Legalism or Beyond (Cambridge Scholars Publishing, 2019), 140.

${ }^{13}$ In the Islamic people circle, this modern era was Islam revival era. Rahman (1984) stated that the revival of Islam was affected by the West invasion, especially in 19 century. Many researchers stated that Islam at that time was in the life and death mode which was affected by the destructive threat and formative influences from the West

${ }^{14}$ Bahder Johan Nasution, 'Kajian Filosofis Tentang Hukum Dan Keadilan Dari Pemikiran Klasik Sampai Pemikiran Modern', Al-Ihkam: Jurnal Hukum \& Pranata Sosial 11, no. 2 (January 2, 2017): 270.

${ }^{15}$ Gunther Teubner, 'How the Law Thinks: Toward a Constructivist Epistemology of Law', in Legal Theory and the Social Sciences (London: Routledge, 2018), 205-235, 210215.
} 
c. Law is an instrument which is implemented consciously in pursuance of actualizing people's political decisions. ${ }^{16}$

In modern life and civilization, the law is more prime in terms of manifestation form than another social life system. ${ }^{17}$ It also reflects justice for people. Law should be appropriate to people's condition. Then, the law should be established based on the appropriate procedure and understandable by people. The modern law system is all of the rules which connect each other, and its rules are organized rationally. For a special case, the general law could be discovered until its origination.

Modern law system components are listed below: ${ }^{18}$

a. Structural element (parts of law system which run in certain mechanism)

b. Substantial element (a factual outcome which is published in the law system in the form of:

1) In concreto law, individual law rule

2) In abstract law, general law rule (the rule of law which is covered by Law)

c. There is a culture element that people behave and norms are included. The relationship between social norms, attitudes, and law affected the law.

The dispute is attached to human life. There are several dispute resolutions:

a. Litigation in court institution

In general, court, qad $\bar{a}^{\prime}$ in the Arabic language, refers to resolving, completing, deciding a law as well as establishing a decision. On the other side, the law should be referred to as obstructing or preventing. It could be concluded that qad̄on's task (court institution) is revealing law instead of establishing it because the law is already faced by judges (established by Allah).

\footnotetext{
${ }^{16}$ Ashk Dahlen, Islamic Law, Epistemology and Modernity: Legal Philosophy in Contemporary Iran (Routledge, 2003), 343.

${ }^{17}$ Abdul Halim Teguh Prasetyo, Barkatullah, Ilmu Hukum dan Filsafat Hukum (Studi Pemikiran Ahli Hukum Sepanjang Zaman) (Yogyakarta: Pustaka Pelajar, 2007), 80-90.

18Mathieu Deflem, Habermas, Modernity and Law (Sage Publications, 1996), 103-104.
} 
In fiqh literature, the court is called as al-qaḍā' referred to resolving or establishing. Then, it is also identified as mahkamah al-qaḍa $\bar{a}^{\prime}$ which is represented as an institution in fulfilling people's needs of justice. On the contrary, the court is an organization that enforcing law and justice.

The court is people's hope foothold in seeking justice or disputing party. In giving law service and justice for society, the court has the main duty such as accepting, analyzing, adjudicating and performing dispute resolution. To accomplish these duties, the court should:

1) Giving fair and humane treatment toward justice seeker.

2) Giving sympathetic treatment and assistance for justice seeker.

3) Giving effective, efficient, thorough and final dispute resolution which gratifies whole people.

b. Non-litigation (outside court institution)

Dispute resolution that happened outside a court institution is identified as an Alternative Dispute Resolution (ADR). ${ }^{19}$ Alternative dispute resolution is growing rapidly in the West and East. Traditional culture emphasized commonality, kinship harmony, primus inter pares which encourage formal dispute resolution outside court. It also emphasized on efficiency and effectivity to encourage civil dispute resolution through Court.20

In general, dispute resolution system through litigation or nonlitigation is a significant part for law enforcement in national life which could not be separated from the power of judge construct as country power executor in law and justice enforcement.

c. Law enforcement.

Law enforcement is described as a process or method in enforcing law norms for real. It is intended to perform normative or written law rule, or which is referred to as laws and regulations.

${ }^{19}$ Henry S. Kramer, Alternative Dispute Resolution in the Work Place (Law Journal Press, 2016), 20.

${ }^{20}$ Jimmy Joses Sembiring M.Hum, Cara Menyelesaikan Sengketa di Luar Pengadilan (Jakarta: VisiMedia, 2011), 10-11. 
Likewise, dispute resolution system in the form of litigation or non-litigation is a crucial part of law enforcement and relates to the power of judge construct as country power executor in law and justice enforcement in pursuance of order and peace of the country.

The purpose of law enforcement is conformity between law and its practice. In sum, there is conformity between deis sein and das sollen. Law is impracticable in real life. However, the idea of law goal substance is law enforcement, legal certainty, and its expediency.

Consequently, order and peace would be established. The independent judiciary as the ideology that its nascent and revolution produced trias politica. It is also known as "the law is supreme"

Montesquieu on trias politica theory intends to separate the power (machtenscheiding), which prevents power absolutism. Therefore, power should be separated from each other. If the country embraces law country ideology, judiciary power should be free from other power intervention. Law should be above all of the things in the life of people and nations. ${ }^{21}$

Therefore, to guarantee and uphold the law supreme, the constitutional Law deliberately separates nation power (separation power). In separating country power, supervisors, caretakers, and corrector of law supreme should be given their function and authority toward judiciary power who are free from intervention and executive power. Consequently, in pursuance of effective and efficient those functions and authority, it needs independent and impartial law institutions. ${ }^{22}$

Independent could be referred to as free from executive intervention, pressure, and intimidation. The demand for independent judiciary power is intended to have an obvious barrier

${ }^{21}$ Herman H.H. Van Erp, Political Reason and Interest: A Philosophical Legitimation of the Political Order in a Pluralistic Society (Taylor and Francis, 2018), 128.

${ }^{22}$ Allen Buchanan, 'Institutional Legitimacy', in Oxford Studies in Political Philosophy, vol. 4 (Oxford University Press, 2018), 53-78, 55. 
between judiciary power and all forms of government intervention such as administration and civil service issues. ${ }^{23}$

Independent judiciary power could be indicated as the 'Universal Declaration of Human Rights', dan 'International Covenant on Civil and Political Rights ${ }^{24}$ the reflection which is regulated "independent and impartial judiciary ". In the Universal Declaration of Human Rights, it is stated in article 10 that "Everyone is entitled in full equality to a fair and public hearing by an independent and impartial tribunal in the determination of his rights and obligations and any criminal charge against him". 25

d. Law principles

Law enforcement as part of human rights and obligation protection in court through its decision is one of rule of law implementation. According to A.V Dicey, they are:

1) Law supremacy

2) Equality

3) Human rights protection in constitution and court decision ${ }^{26}$

Judicature is referred to as a process that is run in court in accepting, analyzing, deciding and adjudicating cases. Therefore, it needs to implement or find "in concreto" law (judges implemented the law to real cases which is faced by them to be executed and stipulated.). it also needs procedural law as maintaining and securing

${ }^{23}$ Ari Wibowo, 'Independensi Kejaksaan Dalam Sistem Peradilan Pidana Indonesia', Istinbath Jurnal Hukum 12, no. 1 (2015): 1-19, https://ejournal.metrouniv.ac.id/index.php/istinbath/ article/view/571, 17.

${ }^{24}$ Oemar Seno Adji, 'Perkembangan Delik Khusus Dalam Masyarakat Yang Mengalami Modernisasi', Jurnal Hukum \& Pembangunan 10, no. 2 (May 1980): 111.

25It was implemented on 17 verse UU No 39 the Year 1999 about human rights. It was stated that "Everyone, without discrimination, has the right to obtain justice by filing petitions, complaints, and lawsuits, both in criminal, civil and administrative cases and tried through a free and impartial judicial process, in accordance with procedural law that guarantees an objective examination by honest and fair judges to get a fair and right decision ".

26J. Finkelman and A. V. Dicey, Introduction to the Study of the Law of the Constitution, n.d. 152-153; Moh. Mahfud M.D, Demokrasi dan Konstitusi di Indonesia (Jakarta: Rineka Cipta, 2000), 50-55. 
instrument in obeying material law. Here, procedural law is referred to as procedural rules which are decided by formal law.

The world "formal" meant as "form" or "procedure" which refers to prioritizing truth form and procedure". Therefore, in the court procedure, it is inadequate to know law material, yet it went beyond it. It should know the methods and procedures stipulated by Law. The attachment of method and form between justice seekers and law upholders should be consolidated to not perform the procedures arbitrarily. Law procedures could be also identified as procedural rules which guaranteed the impartial-objective judiciary and should be strictly and carefully obeyed. ${ }^{27}$

The main goal of the judiciary is seeking justice by implementing the procedures. The procedures are not intended to constrain law upholders in court but assist them in law implementation. Procedural rules are an instrument in pursuance of achieving the goal and procedure followed by the substance materials.

The idea of the procedure is the heart of the law is placed on an important part of the autonomous ethos. Eventually, procedures are an unquestionable guarantee in implementing law fairly. The closeness between law and procedure is originated from a historical bargain of autonomous law. ${ }^{28}$

The importance of procedural decision or procedural law is in pursuance of substantive law implementation. Substantive law consisted of rights and obligations of law subjects while procedural law consisted of remedy which regulating the method of enforcing rights and duties. In other words, formal law is the implementation method performed by law subjects to

${ }^{27}$ Ali Ahmadi, Menguak Teori Hukum \& Teori Peradilan: Legal Theory \& Judicialprudence (Jakarta: Kencana, n.d.), 188-189.

28Suadi Amran, Sosiologi Hukum: Penegakan, Realitas dan Nilai Moralitas Hukum (Edisi Pertama) (Prenada Media, 2018), 212. 
achieve or maintain their rights and other parties fulfilled their duties through the court process. ${ }^{29}$

Procedural law could be categorized as a normative boundary which is absolute toward court power and judges' liberty. Therefore, the court procedure is inadequate by looking for the material, yet it goes beyond it. It should explore forms and procedures regulated by Law. If a violation occurred, then its outcome would be invalid.

Consequently, the procedural decision goes beyond legality and justice. Substantive justice is derivative which the result is expected to be faultless. However, formal justice serves its available privilege patterns and power consistently. The tug-ofwar between procedural justice and substantive justice produce law disciplined encouragement to go beyond autonomous law boundaries.

There are several procedural decisions in procedural law used in court, criminal law procedural and civil law. Criminal law procedural consists of not only rights and duties but also procedural methods which for law upholders institution. On the other side, procedural civil law indicates law series which consists of rules on how people should act in court and how the court implemented the rules or decisions on civil materials. Civil law procedure is aimed to guarantee civil material obedience. Therefore, procedural law consists of civil procedural law implementation, maintenance, and enforcement. ${ }^{30}$

There are several principles in criminal law procedural which became guidance for law upholders in performing their

\footnotetext{
${ }^{29}$ Nyoman Serikat Putra Jaya, 'Hukum (Sanksi) Pidana Adat dalam Pembaharuan Hukum Pidana Nasional', Masalah-Masalah Hukum 45, no. 2 (April 19, 2016): 123-130, 124; Moh. Mahfud MD, 'Islam, Lingkungan Budaya, dan Hukum dalam Perspektif Ketatanegaraan Indonesia', KARSA: Jurnal Sosial dan Budaya Keislaman 24, no. 1 (June 1, 2016): 1-14, 11.

${ }^{30}$ Christoph Antons and Daniel S. Lev, 'Colonial Law and the Genesis of the Indonesian State', in Law and Society in East Asia (Routledge, 2018), 3-20.
} 
duty. They are a presumption of innocence, dissenting opinion, double jeopardy, burden of proof, and court council. ${ }^{31}$

Civil law also consists of several principles as stated by Valerio Grementiere and Joseph Golden such as mediation, law supremacy, equality before the law, proof of recognition, one witness, no witness, not compelling a man to do that which is possible, formal truth, and hearing open to the public.

\section{Research Findings}

\section{Sultan Adam Law Standpoint}

Law was used as a raw material in court institutions of Sharia Court (religious court) ${ }^{32}$ to resolve any type of dispute and Banjarese people's life cases. Law was stipulated on Thursday Muharram 15 th 1251 Hijria at 09.00 in the morning by Sultan Adam. SAL was intended to complete religion and believe his people, prevent disputes among people, assist judges in law determination and make the betterment of his people.

It was described in SAL that not only as guidance for authority in organizing the country or kingdom and its people but also qậdi (judges) and mufti in dispute resolutions (including law material and formal law in court) for Banjar Kingdom's people. ${ }^{33}$ Sultan Adam used the terms "undang-undang" law because it was already used by Banjar people. The meaning of "undang-undang" also indicated law in Islam while the term case was indicated by the article. ${ }^{34}$

\footnotetext{
${ }^{31}$ Lilik Mulyadi, 'Eksistensi Hukum Pidana Adat Di Indonesia: Pengkajian Asas, Norma, Teori, Praktik Dan Prosedurnya', LITIGASI 17, no. 2 (November 29, 2016): 3284-3313.

${ }^{32}$ The existence of religious court was proven by SAL systematic of resolving law cases in the Banjar Kingdom. Even though the valid system was simple, it had a similar point. SAL had more rights than religious court.

${ }^{33}$ Hendra Gunawan, 'Potret Perjalanan Hukum Islam di Indonesia', Jurnal ALMAQASID: Jurnal Ilmu Kesyariahan dan Keperdataan 4, no. 1 (2018): 43-60, http://jurnal. iain-padangsidimpuan.ac.id/index.php/almaqasid/article/view/1418; Ita Syamtasiyah Ahyat, 'Perkembangan Islam Di Kesultanan Banjarmasin', SOSIOHUMANIKA 8, no. 1 (2015): 11-20, http://www.journals.mindamas.com/index.php/sosiohumanika/article/ view/523/521, 12-13.; Abdurrahman Abdurrahman, 'Undang-Undang Sultan Adam 1835 dalam Perspektif Sejarah Hukum', Al-Banjari : Jurnal Ilmiah Ilmu-Ilmu Keislaman 10, no. 2 (November 10, 2011), 174.

${ }^{34}$ Abdurrahman Abdurrahman, 'Undang-Undang Sultan Adam 1835 dalam Perspektif Sejarah Hukum', 175-176.
} 


\section{Several Procedural Decision}

The material contained in SAL was categorized into several law aspects such as procedural aspect or procedural decision in court institutions at that time including mufti's duties, litigation party prohibited to meet judges, decision implementation, adjudication, Bilal and mosque caretaker duties, indictment, indictment deadline, kings and minister's prohibition of intervention for civil cases except judges report to them and judges' duty on analyzing the cases.

In terms of procedural aspect in procedural law, it is listed below:

a. Muftī was prohibited to issue a fatwō for the plaintiff and the plaintiff was also prohibited to ask muftī for issuing a fatwā. This article guaranteed court independency which judges were prohibited to intervene in dispute resolution.

b. Kings, Minister, chief of village or aides were prohibited to intervene the plaintiffs

c. Judges duties were completed after analyzing the cases, witness hearing, previously having deliberation for agreement with the chief of the village before the decision had been reached.

d. All of the decisions should be submitted to the prime minister to get the royal stamp.

e. Mosque caretakers were part of law upholders, so judges could ask them to implement judgment decisions on behalf of Sultan

f. The lawsuit should be submitted first to the defendant and the defendant should respond to it. If within 15 days, the defendant did not respond, judges had the right to issue the adjudications.

Procedural rules are aimed to guarantee the implementations of material decisions in legislation. Formal law is also identified as law which organized maintenance and implementation method of material law. In other words, it consisted of litigation methods to court and the method of how judges reached the decision.

According to Friedman, procedures are an instrument to achieve the goals and follow the substance. By following the substance, it 
would identify which procedural parts were more important. ${ }^{35}$ The material decision contained in the SAL article had been completed with procedural laws. Eventually, it described the law system in the Banjar Kingdom was perfectly developed.

\section{The Dimension of the Sultan Adam Law}

Based on the SAL description above, it could be concluded that SAL preamble comprised the Sultan's dreams of reinforcing his people Islamic Aqeeda and ahl al-sunnah wa al-jamä'ah. Therefore, Banjar people were prevented from heresy at that time. He also expected his people to cling to Madhab Syafii. It could be concluded that SAL contained Islamic decision. The reason why SAL used the term "undang-undang" (law) was to show the kingdom's existence towards the Netherlands who colonized them at that time. ${ }^{36}$

Systematically, SAL did not classify between substantive law and procedural law. It also happened to formal decisions and material decisions. The organization's SAL was simple and disorganized. It did not use the terms of articles and verses, yet it used similar to article and verse terms. ${ }^{37}$ By comprehending SAL, it could be concluded that SAL could be identified as kingdom rules.

Then, law experts have different opinions toward SAL standpoint. By considering SAL written form and structure, they conclude that it was categorized as rule contained modern legal norms. Soeryono Soekanto states that unwritten law is referred to as customary law. If someone discovers in the form of a written document, it could be identified as common law. 38

Further, Amir Hasan Kiai Bondan explains that Sultan Adam used SAL in court affairs which were related to religion, marriage, land acquirement and

${ }^{35}$ Achmad Ali, Menguak Teori Hukum (Legal Theory) dan Teori Peradilan (Judicial Prudence) termasuk Interpretasi Undang-Undang (Legis Prudence) (Jakarta: Kencana Prenada Media Group, 2009), 23.

36Johannes Cornelis Noorlander, Bandjarmasin En de Compagnie in de Tweede Helft Der 18de Eeuw (Leiden: Dubeldeman, 1935), 10.

${ }^{37} \mathrm{Abd}$. Shomad, Hukum Islam-Penormaan Prinsip Syariah dalam Hukum Indonesia (Kencana, 2017), 210-211.

${ }^{38}$ Soerjono Soekanto, Kedudukan dan Peranan Hukum Adat di Indonesia (Jakarta: Kurnia Esa, 1970), 25. 
many more. He also listed law material contained in SAL as followed; Islamic law, Islamic procedural law, agricultural law, fiscal law, and commercial law. 39

Substantially, SAL consisted of procedural law in religious court which contained Fiqh's decision; state officials were prohibited to intervene law upholders (muftī, judges). Law upholders had their independence to perform their duties and functions in law enforcement and justice seekers and law upholders were prohibited to get in touch for the sake of independence. Procedural law is aimed to guarantee the implementation of materials decisions on legislation. Therefore, the law contained litigation or filing the case method and how judges reached the decision. It is in line with Friedman that procedural law is an instrument to achieve the goal, following the substance then the substance would identify which part is important.

\section{Conclusion}

Based on the explanation above, it could be concluded that SAL was written Islamic law decision presented on the legal script. It consisted of procedural decisions in court. The procedural decisions related to the rights and duties of justice seekers and how law upholders implement their rights and duties independently by ignoring the intervention from plaintiffs or authority.

Even though SAL could be seen as a simple and disorganized form, structure, substance and its procedural decisions met modern law aspects.[a]

\section{BIBLIOGRAPHY}

Abdurrahman, Abdurrahman. 'Undang-Undang Sultan Adam 1835 Dalam Perspektif Sejarah Hukum'. Al-Banjari: Jurnal Ilmiah Ilmu-IImu Keislaman 10, no. 2 (November 10, 2011).

Adji, Oemar Seno. 'Perkembangan Delik Khusus Dalam Masyarakat Yang Mengalami Modernisasi'. Jurnal Hukum \& Pembangunan 10, no. 2 (May 1980): 111.

Ahmad Satori. Sketsa Pemikiran Politik Islam. Edited by Akhmad Satori dan Sulaiman Kurdi. 1st ed. Yogyakarta: Deepublish, 2016.

${ }^{39}$ Dede Hidayatullah, 'Peran Kerajaan Banjar Dalam Penulisan Naskah Di Tanah Banjar', Manuskripta 2, no. 1 (2012): 163-179, 170; Abdurrahman Abdurrahman, 'Undang-Undang Sultan Adam 1835 dalam Perspektif Sejarah Hukum', 176. 
https://books.google.co.id/books?id=cpWEDwAAQBAJ\&printsec $=\mathrm{f}$ rontcover\&hl=id\&source=gbs_ge_summary_r\&cad=0\#v=onepage $\&$ $\mathrm{q} \& \mathrm{f}=$ false.

Ahmadi, Ali. Menguak Teori Hukum \& Teori Peradilan: Legal Theory \& Judicialprudence. Jakarta: Kencana, n.d.

Ahyat, Ita Syamtasiyah. 'Perkembangan Islam Di Kesultanan Banjarmasin'. SOSIOHUMANIKA 8, no. 1 (2015): 11-20. http://www.journals.mindamas.com/index.php/sosiohumanika/a rticle/view/523/521.

Ali, Achmad. Menguak Teori Hukum (Legal Theory) Dan Teori Peradilan (Judicial Prudence) Termasuk Interpretasi Undang-Undang (Legis Prudence). Jakarta: Kencana Prenada Media Group, 2009.

Amran, Suadi. Sosiologi Hukum: Penegakan, Realitas dan Nilai Moralitas Hukum (Edisi Pertama). Prenada Media, 2018.

Antons, Christoph, and Daniel S. Lev. 'Colonial Law and the Genesis of the Indonesian State'. In Law and Society in East Asia, 3-20. Routledge, 2018.

Buchanan, Allen. 'Institutional Legitimacy'. In Oxford Studies in Political Philosophy, 4:53-78. Oxford University Press, 2018.

Bulmer, Martin. Sociological Research Methods. Routledge, 2017.

Coolhaas, W. Ph. A Critical Survey of Studies on Dutch Colonial History. Springer Science \& Business Media, 2013.

Dahlen, Ashk. Islamic Law, Epistemology and Modernity: Legal Philosophy in Contemporary Iran. Routledge, 2003.

Deflem, Mathieu. Habermas, Modernity and Law. Sage Publications, 1996.

Dicey, J. Finkelman and A. V. Introduction to the Study of the Law of the Constitution, n.d.

Van Erp, Herman H.H. Political Reason and Interest: A Philosophical Legitimation of the Political Order in a Pluralistic Society. Taylor and Francis, 2018.

Gunawan, Hendra. 'Potret Perjalanan Hukum Islam Di Indonesia'. Jurnal AL-MAQASID: Jurnal Ilmu Kesyariahan dan Keperdataan 4, no. 1 (2018): 43-60. http://jurnal.iainpadangsidimpuan.ac.id/index.php/almaqasid/article/view/1418.

Herlambang Perdana Wiratraman. 'Perkembangan Politik Hukum Peradilan Adat'. Jurnal Mimbar Hukum 30, no. 3 (2018): 488-503. 
https://jurnal.ugm.ac.id/jmh/article/view/38241.

Hidayatullah, Dede. 'Peran Kerajaan Banjar Dalam Penulisan Naskah Di Tanah Banjar'. Manuskripta 2, no. 1 (2012): 163-179.

Jassin, Suparman. Sejarah Peradilan Islam. Bandung: Pustaka Setia, 2015.

Kramer, Henry S. Alternative Dispute Resolution in the Work Place. Law Journal Press, 2016.

M.Hum, Jimmy Joses Sembiring. Cara Menyelesaikan Sengketa di Luar Pengadilan. Jakarta: VisiMedia, 2011.

Mahfud MD, Moh. Demokrasi Dan Konstitusi Di Indonesia. Jakarta: Rineka Cipta, 2000.

- _ - 'Islam, Lingkungan Budaya, Dan Hukum Dalam Perspektif Ketatanegaraan Indonesia'. KARSA: Jurnal Sosial dan Budaya Keislaman 24, no. 1 (June 1, 2016): 1-14.

Muhammad Siddiq Armia. 'Sumbangsih Kerajaan Muslim Indonesia Dalam Pengembangan Peradilan Islam: Analisis Historical Legal Approach'. Jurnal Justicia: Jurnal Ilmu Hukum, Perundang-undangan dan Pranata Sosial 2, no. 2 (2017): 1-16. https://jurnal.arraniry.ac.id/index.php/Justisia/article/view/2653/1906.

Mulyadi, Lilik. 'Eksistensi Hukum Pidana Adat Di Indonesia: Pengkajian Asas, Norma, Teori, Praktik Dan Prosedurnya'. LITIGASI 17, no. 2 (November 29, 2016): 3284.

Nasution, Bahder Johan. 'Kajian Filosofis Tentang Hukum Dan Keadilan Dari Pemikiran Klasik Sampai Pemikiran Modern'. Al-Ihkam: Jurnal Hukum \& Pranata Sosial 11, no. 2 (January 2, 2017): 247.

Nisa Ushulha. 'Kerajaan Banjar Dan Perang Banjar(1859-1905 M)'. UIN Sunan Ampel Malang, 2016. http://digilib.uinsby.ac.id/12904/.

Noorlander, Johannes Cornelis. Bandjarmasin En de Compagnie in de Tweede Helft Der 18de Eeuw. Leiden: Dubeldeman, 1935.

Novak, Marko, and Vojko Strahovnik. Modern Legal Interpretation: Legalism or Beyond. Cambridge Scholars Publishing, 2019.

Putra Jaya, Nyoman Serikat. 'Hukum (Sanksi) Pidana Adat Dalam Pembaharuan Hukum Pidana Nasional'. Masalah-Masalah Hukum 45, no. 2 (April 19, 2016): 123-130.

Ridha, M. Faqih. 'Potret Lain Perjalanan Hukum Di Kerajaan Banjar'. AlBanjari : Jurnal Ilmiah Ilmu-Ilmu Keislaman 12, no. 1 (August 14, 2015).

https://jurnal.uin-antasari.ac.id/index.php/al- 
banjari/article/view/452.

Shomad, Abd. Hukum Islam-Penormaan Prinsip Syariah Dalam Hukum Indonesia. Kencana, 2017.

Soekanto, Soerjono. Kedudukan Dan Peranan Hukum Adat Di Indonesia. Jakarta: Kurnia Esa, 1970.

Suriadi, Ahmad. Syekh Muhammad Arsyad Al-Banjari Dalam Dinamika Politik Kerajaan Banjar Abad XIX. Pusat Penelitian dan penerbitan LP2M IAIN Antasari, 2014.

Teguh Prasetyo, Barkatullah, Abdul Halim. Ilmu Hukum Dan Filsafat Hukum (Studi Pemikiran Ahli Hukum Sepanjang Zaman). Yogyakarta: Pustaka Pelajar, 2007.

Teubner, Gunther. 'How the Law Thinks: Toward a Constructivist Epistemology of Law'. In Legal Theory and the Social Sciences, 205235. London: Routledge, 2018.

Wibowo, Ari. 'Independensi Kejaksaan Dalam Sistem Peradilan Pidana Indonesia'. Istinbath Jurnal Hukum 12, no. 1 (2015): 1-19. https://ejournal.metrouniv.ac.id/index.php/istinbath/article/view/571. 